\title{
Arendt og Kafka
}

\section{Retten til at have rettigheder i Franz Kafkas "Forvandlingen"}

Hvis man oplever et bureaukrati, der træffer uigennemskuelige beslutninger hen over hovedet på en, vil man med meget stor sandsynlighed bruge ordet "kafkask". $\mathrm{Nu}$ om dage fås Franz Kafka ikke bare som tv, tegneserie og t-shirt, men også som tillægsord. Ordet har sin oprindelse i efterkrigstidens eksistentialistiske Kafkaforskning, hvor man havde problemer med at se meningen i forfatterskabet og derfor valgte at læse det som en illustration af menneskelivets absurde meningsløshed. Grundbetydningen af det 'kafkaske' er således en form for eksistentialistisk meningsløshed, suppleret med en forestilling om byen Prags krogede gader og med en forestilling om privatpersonen Kafkas ikke mindre labyrintiske familie- og kærlighedsliv.

På dansk grund er den "kafkaske" Kafkalæsning først og fremmest blevet formuleret af Villy Sørensen, som i sin på mange måder imponerende Kafkas digtning (1968) forklarer, hvordan man skal forstå begrebet: "At føre de sociale konflikter tilbage på psykiske og at lade de psykiske komplekser træde frem i den sociale omverden, - det er netop det særlig 'kafkaske”' (Sørensen 1980, 71). Ifølge Villy Sørensen handler et 'kafkask' værk altså ikke om menneskenes liv i sociale og politiske fællesskaber; det bruger blot det sociale liv som en projektionsflade for det enkelte menneskes psykiske komplekser. ${ }^{.}$Kafkas værker er tæt befolket med bipersoner advokater, fædre, kærester, hjælpere, tjenestepiger osv. - men i de fortolkninger, der er styret af en forestilling om det 'kafkaske', har bipersonerne en besynderlig tendens til at forsvinde ud af billedet på bekostning af den ene hovedperson. Hvis de overhovedet bliver nævnt, bliver de gerne tolket som en slags allegoriske inkarnationer af en problemstilling i hovedpersonens indre liv.

'Kafkask' er et nyttigt ord i mange sammenhænge, men efter min mening er det ikke velegnet til at forstå Kafkas forfatterskab med. Kafkas værker er ganske enkelt ikke 'kafkaske'; de nøjes ikke med at bruge det sociale liv som en symbolsk iscenesættelse af intrasubjektive komplekser, men giver tværtimod en omhyggelig analyse af intersubjektive praksisser. Dette har afgørende konsekvenser for forståelsen af 
Kafkas behandling af retfærdigheden, som jeg skal beskæftige mig med i denne artikel. En 'kafkask' optik vil se retfærdigheden fra det ensomme menneskes perspektiv, og set herfra kommer det til at handle om truende og irrationelle magter, der fælder en ødelæggende dom over det magtesløse menneske. Forestillingen om det 'kafkaske' er således tæt forbundet med en såkaldt retfærdighedskritik, og det vil sige med en analyse, der afdækker, hvordan en bestemt retfærdighedspraksis knuser det enkelte menneskes frihed.

Hannah Arendt foreslår en meget anderledes tilgang til retfærdigheden hos Kafka. For hende knuser retten ikke kun det enkelte menneske, den beskytter også det enkelte menneske mod vilkårlig magtudøvelse og i yderste konsekvens mod det nøgne mord (Arendt 1978, 90). Problemet er således ikke bare retten, men i mindst lige så høj grad den mangel på ret, der gør det enkelte menneske forsvarsløst over for andre mennesker. I to tidlige essays om Kafka, begge fra 1944, foreslår Arendt at fortolke Kafkas hovedpersoner som mennesker, der kæmper for deres rettigheder. "Franz Kafka: en revurdering" gennemgår Kafkas tre romanfragmenter, hvis hovedpersoner ifølge Arendt befinder sig i "nødvendighedens, uretfærdighedens og løgnens verden", men som alligevel formår at stille et krav om "menneskets umistelige rettigheder" (Arendt 2010, 139f). I "The Jew as Pariah" skriver Arendt ikke blot om Kafka, men også om Heinrich Heine, Bernard Lazare og Charlie Chaplin, som alle kredser om rettighedsløshedens problem. Deres fiktionsværker handler ifølge Arendt om den foragtede jødiske paria, der af det omgivende samfund betragtes som nobody og nonentity, et menneske uden "retslig opholdstilladelse" (Arendt 1978, 83, 82, 88). I det sidstnævnte essay opsummerer Arendt sin Kafka-læsning ved at formulere sin egen mening om, hvor vigtigt det er at leve et "nominelt" liv, og det vil i denne sammenhæng sige et liv, hvor man ikke svæver i fri luft som en paria uden for fællesskabets regler, men udfolder sin frihed inden for reglerne: "Et sandt menneskeliv lader sig ikke leve af mennesker der føler sig afsondret fra menneskehedens basale og enkle love, og heller ikke af mennesker der vælger at leve i et vakuum, selvom det er forfølgelse der har fået dem til det. Menneskers liv skal være nominelt, ikke exceptionelt" (Arendt 1978, 89).

I denne formulering taler Arendt ikke bare om Kafkas hovedpersoner eller om jøder i almindelighed, men også om sig selv. Efter hun flygtede fra Tyskland i 1937, og indtil hun opnåede amerikansk statsborgerskab i 1951, befandt Arendt sig i et retsligt og politisk vakuum. En af de centrale ambitioner i Arendts tidlige forfatterskab er at forstå, hvad det vil sige at leve som statsløs flygtning. Op gennem 1930'erne skrev hun en afhandling om den romantiske forfatterinde Rahel Varnhagen, hvor hun fokuserede på den jødiske Varnhagens billede af sig selv som ulykkeligt ekskluderet fra samfundet (Arendt 1974, 17). Året før de to Kafka-essays skrev hun det mere personlige essay "We Refugees" om flygtningens oplevelse af identitetstab (Arendt 2007). Og i The Origins of Totalitarianism, der udkom i 1951, syv år efter de to essays om Kafka, analyserer Arendt flygtningens problemer i det berømte kapitel om menneskerettighederne. Arendt tager her udgangspunkt i årene efter Første Verdenskrig, hvor nationalistiske og antisemitiske strømninger fik Europas nationalstater til at skille sig af med deres uønskede etniske minoriteter. Hermed blev millioner af angiveligt "overflødige" personer tvunget til at leve uden for lovens 
grænse i en form for organiseret lovløshed, der blev administreret af ukontrollerede politimyndigheder (Arendt 1979, 288). Ifølge Arendt demonstrerede mellemkrigstidens flygtningemasser behovet for en basal ret til at leve som et rettighedsbærende medlem af samfundet og ikke som en paria i et normativt vakuum:

4 Først da der dukkede millioner af mennesker op som havde tabt og ikke kunne genvinde disse rettigheder, blev vi opmærksomme på eksistensen af en ret til at have rettigheder (og det vil sige til at leve inden for en ramme hvor man bliver bedømt på sine handlinger og meninger) lige så vel som retten til at tilhøre en eller anden slags organiseret fællesskab. (ibid., 296)

Arendts to tidlige essays om Kafka er skæmmet af nogle af de filologiske misforståelser, der prægede Kafka-receptionens første, vilde år; ikke mindst den opfattelse at Kafkas første romanskitse Den forsvundne (der i mange år har været kendt under Max Brods titel Amerika) skulle være skrevet i slutningen af Kafkas forfatterskab. Ikke desto mindre vil jeg i denne artikel argumentere for, at Arendt har fat i noget helt afgørende. Det, som Arendt kalder "de rettighedsløses katastrofe" (the calamity of the rightless), er, vil jeg hævde, et centralt tema i Kafkas forfatterskab. Kafka var en generation ældre og døde yngre end Arendt. Selvom han på nært hold kunne følge antisemitismens fremmarch i Bøhmen og nogle af dens tidlige politiske konsekvenser, levede han ikke længe nok til at se, hvordan hans familie og venner mistede deres medborgerskab og enten flygtede til Palæstina eller forsvandt i lejrene. Hvor Kafka oplevede, hvordan det juridiske og politiske vakuum åbnede sig midt i det civiliserede Europa, bevidnede Arendt, hvordan det mundede ud i udryddelseslejrene. I denne dystre historiske situation var de begge interesserede ikke så meget i enkelte specifikke rettigheder, men snarere i det fundamentale spørgsmål om retten til at have rettigheder.

Ikke mindst takket være Giorgio Agambens videretænkning af Arendt har vi i dag vænnet os til at beskrive de rettighedsløses katastrofe som en undtagelsestilstand: en zone af anomi midt i samfundets væv af regler. Jeg vil imidlertid forsøge at vise, at det er Arendts snarere end Agambens analyse af det normative vakuum, der giver et frugtbart udgangspunkt for en tolkning af Kafkas forfatterskab. I artiklens første del vil jeg dels gennemgå de fire vigtigste træk i Arendts analyse af de rettighedsløses katastrofe, dels gennemspille disse fire træk i en (nødvendigvis vældig komprimeret) læsning af Kafkas store fortælling "Forvandlingen" fra 1912. I artiklens anden halvdel vil jeg fokusere på forskellene mellem Arendts og Kafkas tilgang til de rettighedsløses katastrofe. Her vil jeg argumentere for, at Arendt betragter de rettighedsløses katastrofe som et spørgsmål om ret, hvorimod Kafka snarere anskuer den som et spørgsmål om retfærdighed. Forskellen mellem ret og retfærdighed er hårfin, men ikke desto mindre har den afgørende konsekvenser for forståelsen af, hvordan retten til at have rettigheder kan komme til syne i litteraturen. 
I.

Arendts analyse af de rettighedsløses katastrofe tager udgangspunkt i den klassiske sondring mellem privat og offentligt, mellem oikos og polis, dominium og res publica. I den græske bystat bestod husholdningen, oikos, af herren og hans kone, børn, slaver og husdyr, og denne økonomiske enhed varetog bystatens produktive og reproduktive opgaver. Ifølge Aristoteles er relationerne mellem borgerne i byen, polis, reguleret af love, hvorimod huset, oikos, udgør et hul i netværket af juridiske rettigheder. Og eftersom byens love ikke når ind bag husholdningens fire vægge, findes der ingen retfærdighed her, skriver Aristoteles i Etikken (Aristoteles 2000, 135). Som Arendt resumerer Aristoteles i Menneskets vilkår, er slaven "per definition uden for lovens sfære" (Arendt 2005, 331). Ifølge Arendt er den moderne flygtning, ligesom den antikke slave, en fange af oikos:

6 Det menneske der har mistet sin plads i et fællesskab, sin politiske status i sin tids kampe, og den retslige personlighed som gør hans handlinger og en del af hans skæbne til et sammenhængende hele, har blot de egenskaber tilbage som normalt kun kan blive artikuleret i det private livs sfære, og som må forblive ukvalificeret, blot eksistens i alle offentlige anliggender. (Arendt 1979, 301)

Ligesom Agambens "nøgne liv" er Arendts "blotte eksistens" et menneske, hvis liv er bestemt af det politiske, men som ikke selv har status som politisk subjekt. Arendt fremhæver fire træk ved de rettighedsløses katastrofe, og de har alle deres idéhistoriske baggrund i Aristoteles' bemærkninger om det lovløse liv i oikos.

\section{Tilfældighed}

Ifølge Arendt er den rettighedsløse flygtning for det første eksponeret for privatsfærens tilfældigheder. Det ovenstående citat om flygtningens mangel på politisk status fortsætter:

64 Denne blotte eksistens, det vil sige alt det som på mystisk vis er givet os ved fødslen og som indbefatter vores kroppes form og vores hjerners talenter, kan man kun omgås adækvat i venskabets og sympatiens uforudsigelige tilfældigheder, eller ved kærlighedens store og uberegnelige nåde, som med Augustin siger 'Volo ut sis (Jeg vil at du skal være), uden at være i stand til at give nogen bestemt grund for denne højeste og mest uovertrufne bekræftelse.

Når man er ekskluderet fra det regulerede politiske rum, er man udleveret til denne verdens kontingenser. Det gælder dels den genetiske tilfældighed, der bestemmer hvordan ens krop er faldet ud, og hvor mange talenter man har at gøre godt med; dels gælder det den sociale tilfældighed, der karakteriser den form for sociale relationer, der ikke bygger på almene regler, men på menneskenes omskiftelige følelser over for hinandens fysiske og psykiske særegenheder. Det er denne grundløshed, som Arendt formulerer med det augustinske nådesbegreb: det rettighedsløse subjekt indgår i sociale relationer, der har karakter af nådeshandlinger, for der er tale om en form for anerkendelse, som der ikke kan gives nogen gode begrundelser for, 
sådan som eksempelvis kærligheden ikke kan begrundes med almene grunde. Kærlighedens "Jeg vil at du skal være" skal altså her forstås som en modsætning til retfærdighedens "Du har berettigelse til at være". Det er det, som landsbyboerne ifølge Arendt forsøger at forklare hovedpersonen i romanfragmentet Slottet: "de forsøger at overbevise $\mathrm{K}$. om, at han mangler erfaring og ikke ved, at hele livet er konstitueret og domineret af nåde og unåde, af velsignelse og forbandelse, og at dette er lige så uforklarligt, lige så tilfældigt som held og uheld" (Arendt 2010, 141).

Efter at Gregor Samsa i Kafkas fortælling "Forvandlingen" en morgen er vågnet op som et billelignende kryb, er familien Samsas lejlighed meget tydeligt gennemskåret af en grænse mellem offentligt og privat. Prokuristen fra Gregors arbejde hører hjemme i en offentlig sfære, mens moderen og søsteren færdes i en privat sfære, og et sted midt imellem de to sfærer svæver Gregors far. I den offentlige sfære er den sociale interaktion baseret på regler. I sine monologer til Gregor henviser prokuristen til en række almene regler om, hvordan tingene burde være. Gregor er handelsrejsende, og det viser sig, at hans præstationer i den sidste tid har været meget utilfredsstillende; det skyldes årstiden, medgiver prokuristen, "men en årstid hvor der ikke gøres forretninger, findes overhovedet ikke, hr. Samsa, den må ikke findes" (Kafka 2008, 86). Prokuristen tager ikke højde for tilfældighederne i sæsonudsvingene, men henviser alene til den almene regel, der bestemmer, hvad der må og ikke må findes. Det er i det hele taget tydeligt, at prokuristen bevæger sig omkring i et juridisk eller quasi-juridisk univers, eksempelvis når han taler om sin manglende lyst til at "træde i skranken" for Gregor, som om de alle sammen allerede befandt sig foran en domstol (ibid.).

I den private sfære handler den sociale interaktion ikke om regler, men derimod om omsorg og hensyn. Det er "den opmærksomme søster" (s. 100), der påtager sig den daglige pleje af Gregor, og hendes kærlige opmærksomhed er ikke rettet mod almene regler, men kun mod Gregors særegne behov. Hun sætter en ære i at finde ud af, hvordan hun kan gøre Gregor en "særlig tjeneste" (s. 111), eksempelvis ved at finde frem til den helt rigtige mad til ham eller ved at stille stolen hen til vinduet da hun en dag tilfældigvis bemærker, at han godt kan lide at kravle op og kigge ud. Moderens og søsterens omsorg bygger altså på kærlighed, ikke på retfærdighed. Formuleret med Arendt og Aristoteles befinder Gregor sig "uden for lovens sfære", når han har med moderen og søsteren at gøre; de siger "Jeg vil at du skal være" til ham, ikke "Du har berettigelse til at være". Eftersom kvindernes gode gerninger har karakter af nådeshandlinger, der ikke baserer sig på almene rettigheder, er det umuligt for Gregor at stille krav: "Hvis hun ikke gjorde det af sig selv, ville han hellere gå til af sult end at gøre hende opmærksom på det, selvom han egentlig følte stærk trang til styrte frem fra kanapéen, kaste sig for søsterens fødder og bede hende om et eller andet godt at spise" (s. 95). Derfor er det meget konsekvent, at det er søsteren der til sidst - efter hun længe har været træt af at omfatte den besværlige Gregor med kærlig "Zartgefühl” - fælder dødsdommen over ham: “Kære forældre,' sagde søsteren og slog som en indledning hånden i bordet, 'sådan kan det ikke blive ved at gå”' (s. 118). Ligesom flygtningen efter Første Verdenskrig er Gregor udleveret til privatsfæren tilfældigheder og uforudsigeligheder, her med søsteren i rollen som en arbitrært handlende politimyndighed. 


\section{Umenneskelighed}

Ifølge Arendts analyse af de rettighedsløses katastrofe er flygtningen ikke blot ekskluderet fra det politiske rum, men også fra menneskearten. Når flygtningen befinder sig i et juridisk og legalt vakuum, skriver Arendt, har hun kun sin abstrakte, nøgne menneskelighed tilbage og intet andet end den (Arendt 1979, 297). Denne nøgne menneskelighed viser sig i virkeligheden at være en ikke-menneskelighed. De fuldgyldige medlemmer af samfundet opfatter den rettighedsløse som en "vild", som et "dyr", eller - hvis hun er heldig nok til at være en genial kunstner eller videnskabsmand - som "en slags monster" eller "en hund med et navn" (ibid., 287). Også på dette punkt ligger Arendt i direkte forlængelse af Aristoteles, der beskriver herren og slaven som to væsener, der er lige så ontologisk forskellige som mennesket og det vilde dyr (Aristoteles 1997, 83). Arendt insisterer endda på, at dehumaniseringen af den moderne flygtning er endnu værre end dehumaniseringen af den antikke slave, som trods alt endnu tilhørte det menneskelige fællesskab: "Mennesket, viser det sig, kan miste alle de såkaldte menneskerettigheder uden at miste sin væsentligste egenskab som menneske, sin menneskelige værdighed. Kun tabet af et ethvert politisk fællesskab kan udstøde ham fra menneskeheden" (Arendt 1979, 297).

Kafkas "Forvandlingen" tilbyder en meget konkret iscenesættelse af denne grænse mellem menneske og dyr. Gregor er vel at mærke ikke bare blevet forvandlet til en gigantisk bille, men snarere til et hybridt monster, der gennem det meste af fortællingen balancerer på grænsen mellem menneske og dyr. Efter at han er vågnet op som et kryb, er hans første handling at kravle ud af sengen og forsøge at åbne døren til sit værelse med munden, fordi han ikke har nogen hænder, men kun sprællende billeben. Den meget omhyggelige beskrivelse af, hvordan Gregor med stort besvær rejser sig op, er en slags darwinistisk farce om et lavtstående dyr, der forsøger at kæmpe sig op ad evolutionsstigen, så det kan komme til at stå oprejst, selvom det ikke har nogen rygrad. Denne balancegang på grænsen mellem menneske og dyr sættes der en stopper for til sidst i fortællingen, da søsteren fælder den allerede omtalte dom over Gregor:

46 "Kære forældre," sagde søsteren og slog som en indledning hånden mod bordet, "sådan kan det ikke blive ved at gå. Det kan godt være I ikke forstår det, men det gør jeg. Jeg vil ikke nævne min broders navn foran dette udyr og siger derfor blot: vi må forsøge at skaffe os af med det. Vi har gjort hvad der var menneskeligt muligt for at pleje og udholde det, jeg tror ikke at nogen kan bebrejde os det mindste." $(2008,118)$

Søsteren siger ikke "vi må forsøge at skaffe os af med ham," men "vi må forsøge at skaffe os af med det," og med dette diskrete skift af stedord skubber hun ham ud over grænsen for det menneskelige fællesskab. Dehumaniseringen er at blive frataget sit menneskelige navn og sit menneskelige pronomen, og efter denne symbolske død er den fysiske død en ren formalitet. Da Gregor endelig er gået bort, stikker hushjælpen hovedet ind i den dagligstue, hvor familien Samsa sidder, og siger: "altså, I behøver ikke at gøre jer nogen bekymringer om hvordan stadset ved siden af skal skaffes væk. Det er allerede blevet ordnet." På dette tidspunkt har Gregor ikke status som subjekt, men som "Zeug", og det vil sige som noget tingsagtigt stads, 
som man ikke begraver, men skaffer af vejen. Ligesom de rettighedsløse senere i det 20. århundrede er Gregor et ikke-menneskeligt “Zeug”, der ikke har krav på en begravelse.

\section{Ulighed}

Ifølge Arendt befinder flygtningen sig i en verden præget af ulige herredømmeforhold. Dette er det tredje træk, som hun fremhæver i de rettighedsløses katastrofe:

4 Hele sfæren af det blot givne, der i et civiliseret samfund er forlagt til det private liv, er en permanent trussel mod den offentlige sfære, fordi den offentlige sfære er lige så konsistent baseret på lighedens lov, som den private sfære er baseret på loven om universel forskel og forskellighed. Lighed, i modsætning til alt hvad der har at gøre med den blotte eksistens, er os ikke givet, men er et resultat af menneskelig organisation for så vidt som den er vejledt af retfærdighedens princip. (Arendt 1979, 301)

Ifølge Aristoteles er oikos' patriarkalske herredømmeforhold - den såkaldte oikonomia - per definition ulige (Aristoteles 1997, 158). I Arendts resumé er "familieoverhovedets magt uindskrænket og despotisk", når han udsteder ordrer til sin kone og sine børn, slaver og husdyr (Arendt 2005, 53). Det er først, når husherren forlader huset og bevæger sig ud i byen, at han bliver i stand til at leve et liv mellem ligemænd, nemlig side om side med bystatens andre husherrer, som også har tid tilovers til at deltage i politiske drøftelser (s. 58).

I "Forvandlingen" er Kafka meget omhyggelig med at optegne grænsen mellem de fornuftige grunde, der gælder i det politiske rum, og den mere rå magt, der ligger til grund for livet i oikos. "Moderen ville i øvrigt forholdsvis hurtigt besøge Gregor, men faderen og søsteren holdt hende først tilbage med fornuftsgrunde, som Gregor hørte meget opmærksomt på, og som han fuldstændig bifaldt. Senere måtte man imidlertid holde hende tilbage med magt" (s. 102). Den rå magt, der "imidlertid" befinder sig nede under de civiliserede grunde, bliver ikke mindst tydelig i en scene, hvor Gregor forlader sit værelse og dermed overskrider grænsen mellem dyregrotte og menneskelejlighed. Da den rasende far genner ham på plads i familiens sociale orden, bliver det tydeligt, at oikos hviler på en form for magt, der mest af alt minder om den vold, som mennesker udøver over for biller. Gregor føler nemlig billens instinktive rædsel for det magtfulde menneskes skosåler: eftersom faren løfter sine fødder usædvanligt højt, bliver Gregor "forbavset over hvor kæmpestore hans støvlesåler var” (s. 108). Ligesom den statsløse flygtning bevæger Gregor sig i en social virkelighed uden lighed mellem mennesker.

\section{Sprogløshed}

Ifølge Arendts analyse af de rettighedsløses katastrofe bliver flygtningen ikke bare berøvet sin menneskelige status, men også sin menneskelige stemme, når hun bliver lukket inde i oikos. I The Origins of Totalitarianism lægger Arendt særlig vægt på dette fjerde træk: "The fundamental deprivation of human rights is manifested first and above all in the deprivation of a place in the world which makes opinions significant and actions effective" (s. 296). Flygtningen er politisk betydningsløs, for 
så vidt som hendes ord og handlinger ikke giver mening på den offentlige scene. Hun er kastet tilbage på husholdningen mørke baggrund, og det vil sige på en uflyttelig og skæbneagtig sfære, hvor mennesket ikke kan ændre ved verden og ikke kan handle i egentlig - og det vil hos Arendt sige politisk - forstand (s. 302). Også dette træk er fremtrædende i Aristoteles' beskrivelse af huset. Slaven har ifølge Aristoteles ikke nogen deliberativ evne og er derfor ude af stand til at deltage i bystatens fælles rådslagning (kritiké) (Aristoteles 1997, 100). Bortset fra husherren er medlemmerne af oikos kun udstyret med en "stemme" (phone), som kan bruges til at tilkendegive smerte og lyst, men som man også kan finde hos andre levende væsener. De besidder ikke "talen" (logos), som mennesker bruger til at forklare, hvad der er retfærdigt og uretfærdigt (ibid., 78). I essayet "The Jew as Pariah" gentager Arendt denne aristoteliske formulering i en kommentar til hovedpersonen i Kafkas roman Slottet, som bliver dybt forarget over slotsembedsmændenes absurde dispositioner, men som alligevel ikke har tilladelse til at foretage "den simpleste undersøgelse af hvad der er ret og uret" (Arendt 1978, 87).

Da søsteren fælder den afsluttende dom over Gregor, slår hun "som en indledning hånden i bordet". Denne gestus hører hjemme i et mødelokale, hvor man kan understrege et indlæg ved at slå hånden i forhandlingsbordet. Efter den første morgens chok bliver lejlighedens spisebord forvandlet til et forhandlingsbord, hvor familiefællesskabet drøfter, hvordan de sammen skal håndtere den ubehagelige situation: "I to dage kunne der ved alle måltider høres rådslagninger om hvordan man nu skulle forholde sig" (s. 97). Den første morgen forestiller Gregor sig, at han også skal deltage i denne deliberative proces, men det viser sig at han ikke har evnerne til det:

4 For at få så klar en stemme som muligt til de afgørende diskussioner der nærmede sig, hostede han en smule, idet han ganske vist bestræbte sig på at gøre det helt dæmpet da allerede denne lyd muligvis lød anderledes end en menneskelig hosten, hvilket han ikke længere troede sig i stand til at afgøre. I værelset ved siden af var der i mellemtiden blevet helt stille. Måske sad forældrene ved bordet sammen med prokuristen og hviskede, måske lænede de sig alle mod døren og lyttede. (s. 88)

Selvfølgelig er der ingen uden for døren, der forstår, hvad Gregor siger. "Forstod De et ord af det hele?" spørger prokuristen, da Gregor forsøger at tale: "Det var en dyrestemme" (s. 87). Formuleret med Aristoteles kan de uartikulerede lyde inde fra Gregors værelse betegnes som en dyrisk stemme og ikke som en menneskelig tale. Ligesom flygtningen i årene efter Første Verdenskrig har Gregor mistet sin offentlige stemme.

Arendt og Kafka er således fælles om at analysere rettighedsløshedens katastrofe snarere end enkeltstående rettigheder. Hos dem begge åbner denne undtagelsestilstand sig i den klaustrofobiske privatsfære, og hos dem begge kommer den til udtryk i de fire under-katastrofer tilfældighed, umenneskelighed, ulighed og sprogløshed. Vakuum fås selvfølgelig i mange forskellige størrelser. I mellemkrigstiden var det millioner af flygtninge, der pludselig befandt sig i et retsligt tomrum af globale dimensioner; i familien Samsas lejlighed er det kun en enkelt person, og 
dette vakuum er nogenlunde på størrelse med Gregors lidt for lille værelse. Den afgørende forskel mellem Arendt og Kafka ligger imidlertid ikke så meget i, hvad de analyserer, men snarere i hvordan de analyserer de rettighedsløses katastrofe. For at formulere det lidt stiliseret: hvor Arendt analyserer de rettighedsløses katastrofe som et spørgsmål om ret, analyserer Kafka katastrofen som et spørgsmål om retfærdighed. Denne sondring kunne lyde som en strid om ord, og det er den også et stykke ad vejen. I den resterende del af artiklen skal jeg forsøge at vise, at sondringen faktisk indebærer to forskellige tilgange til det retslige vakuum og dermed også to forskellige forestillinger om, hvordan litteraturen kan behandle denne katastrofe.

II.

\section{Uretfærdighed}

Arendt analyserer som sagt de rettighedsløses katastrofe som et spørgsmål om ret. Helt konkret er kapitlet om menneskerettighederne i The Origin of Totalitarianism en reaktion på FN’s Verdenserklæring om Menneskerettighederne, der var blevet vedtaget i 1948, og som hævdede ethvert menneskes medfødte og fundamentale ret til beskyttelse også uden for nationalstatens retslige rammer. Ifølge Arendt havde nationalstaternes sammenbrud i mellemkrigstiden demonstreret, at der ikke findes den slags universelle rettigheder, som er garanteret af Naturen eller af Gud; der findes kun de borgerrettigheder, der har gyldighed inden for grænserne af et bestemt politisk rum. Som Arendt skriver i et tidligere essay om menneskerettighederne, gjorde de store flygtningestrømme det sørgeligt klart, at "verden ikke fandt noget som helst helligt i den abstrakte nøgenhed i det at være menneske" (Arendt 1949, 31). Af den grund er Arendt grundlæggende enig med Edmund Burkes berømte kritik af menneskerettighederne som "monstrøse" metafysiske abstraktioner, der ikke har rod i nogen juridisk eller politisk virkelighed (Burke 1987, 9). Det er imidlertid afgørende, at Arendt ikke blot er ude på at foretage en dekonstruktion af menneskerettighederne, men snarere på at foreslå en alternativ konstruktion af én grundlæggende menneskeret, der måske kunne være robust nok til at beskytte alle mennesker mod rettighedsløshedens katastrofe. I indledningen til The Origins of Totalitarianism skriver Arendt, at den menneskelige værdighed, efter antisemitismen, imperialismen og totalitarianismen, "har brug for en ny garanti som kun kan findes i et nyt politisk princip, i en ny lov på jorden, hvis gyldighed denne gang må omfatte hele menneskeheden" (Arendt 1979, xi). Dette er ikke stedet til at gå ind i Arendt-forskningens diskussioner om, hvordan man skal forstå en rettighed, der hverken er garanteret af nationalstaten eller Naturen, men derimod af et begreb om menneskeheden som helhed. ${ }^{2}$ Når det kommer til stykket, er Arendts egne formuleringer ret uklare på det punkt. Jeg vil nøjes med at understrege den indlysende pointe, at Arendt beskriver de rettighedsløses katastrofe som et spørgsmål om ret. Retten til at have rettigheder er ganske vist en mere fundamental form for ret, der danner grundlag for alle andre rettigheder: den er, med Arendts formulering, "den ene rettighed uden hvilken ingen anden rettighed kan materialisere sig" (Arendt 1949, 37). Men der er ikke desto mindre stadig tale om en ret, en slags quasi-juridisk krav, der er garanteret af en "ny lov på jorden". 
Denne grundlæggende ret ikke har noget at gøre med vores gængse forestillinger om retfærdighed, understreger Arendt:

4 De rettighedsløses katastrofe [the calamity of the rightless] er ikke at de har mistet deres liv, frihed og stræben efter lykke, eller mistet deres lighed for loven og deres meningsfrihed - formler der blev designet til at løse problemer inden for eksisterende fællesskaber men at de ikke længere tilhører noget som helst fællesskab. Deres kval er ikke at de ikke er lige foran loven, men at der ikke eksisterer nogen lov for dem; ikke at de er undertrykte, men at der ikke engang er nogen der vil undertrykke dem [...]. Noget mere meget fundamentalt end frihed og retfærdighed, som er borgernes rettigheder, er på spil når det at tilhøre det fællesskab som man blev født ind i, ikke længere er en selvfølgelighed, og det ikke at tilhøre det ikke længere er en valgfrihed. (Arendt 1979, 295-296)

I Arendts vokabular beskæftiger retfærdigheden sig udelukkende med de problemer, der dukker op inden for givne fællesskaber. Og eftersom retten til at have rettigheder ikke rettigheder for medlemmer, men derimod retten til medlemskab, har vi ifølge Arendt at gøre med noget, der er "meget mere fundamentalt end retfærdighed". Jeg vil imidlertid argumentere for, at det Arendt forstår som noget meget mere fundamentalt end retfærdighed, snarere må forstås som en meget mere fundamental form for retfærdighed. Når Arendt i sine tidlige værker beskriver det problem, som hun kalder mere fundamentalt end retfærdighed, er det tydeligt, at hun faktisk beskriver et retfærdighedsproblem. Ifølge Arendt er Rahel Varnhagen "bitter" og har en "følelse af at være blevet forurettet" af det ikke-jødiske samfund(Arendt 1974, 17). Kafkas hovedpersoner er ofre for "den største forurettelse" (the greatest injury), når samfundet reducerer dem til retløse nobodies (Arendt 1978, 82). De lever i "nødvendighedens, uretfærdighedens og løgnens verden" (Arendt 2010, 139). Og de statsløse flygtninge, hedder det i The Origins of Totalitarianism, er underlagt en arbitrært handlende politistyrke, over for hvilken man hverken kan forsvare sig med advokater eller med retslige appeller: "Privilegier i nogle tilfælde, uretfærdigheder i de fleste andre: velsignelse og fordømmelse bliver udmålt til dem efter tilfældighedsprincippet og uden nogen som helst forbindelse til hvad de gør, gjorde eller vil kunne gøre" (Arendt 1979, 296).

De fleste moderne retfærdighedsteoretikere diskuterer retten til at have rettigheder som en form for retfærdighed og ikke som noget, der på en eller anden måde går forud for retfærdigheden. Den politiske filosof Nancy Fraser har givet et af de klareste og mest systematiske overblik over den aktuelle diskussion i Scales of Justice (2008), hvor hun sondrer mellem to forskellige niveauer af retfærdighed. På det første niveau handler retfærdigheden om distributionen af sociale goder (og om de procedurale principper, der gælder for denne distribution); på det andet og mere grundlæggende niveau handler retfærdigheden om vores fælles og ofte ureflekterede forestillinger om retfærdighed, det vil sige den baggrund, der bestemmer, hvad der kan gøres til en sag for retfærdigheden, hvordan retfærdigheden skal ske fyldest, og hvem der kan rejse et krav om retfærdighed, osv. Når det drejer sig om det sidste af disse spørgsmål - spørgsmålet om retfærdighedens hvem - henviser Fraser eksplicit til Arendt som den første, der gør opmærksom på den "politisk døde" 
ikke-person og dermed på retten til at have rettigheder (s. 19). "Hvad der er på tale her, er retfærdighedens omfang [the scope of justice], den ramme inden for hvilken retfærdigheden gælder: hvem tæller som subjekt for retfærdighed i en bestemt sag? Hvis interesserer og behov fortjener at komme i betragtning? Hvem tilhører kredsen af dem der har krav på lige hensyn?" (Fraser 2008a, 123). På dette grundlæggende niveau er problemet ikke, hvordan ting skal fordeles retfærdigt, men hvem der overhovedet er relevant for denne fordeling. Her er altså tale om en "dybere" form for uretfærdighed eller om en form for "meta-uretfærdighed" (Fraser 2008b, 19). Formuleret med Michael Walzer, der åbnede den aktuelle diskussion af retfærdighedens omfang med sin indflydelsesrige Spheres of Justice (1983), handler retfærdigheden på dette niveau ikke om fordelingen af sociale goder mellem et samfunds medlemmer, men derimod om fordelingen af medlemskab (Walzer 1983, 31).

I et par situationer føler Gregor Samsa sig uretfærdigt behandlet på retfærdighedens første niveau (som var det, der handlede om fordelingen af materielle goder). Det gælder eksempelvis, når han inde på sit værelse lægger planer om, "hvordan han skulle komme ud i spisekammeret for at tage hvad der tilkom ham" (s. 112). Det er imidlertid afgørende, at Gregor på dette tidspunkt af historien ikke er sulten længere: det drejer sig ikke længere om retfærdighedens indhold, men derimod om dens omfang: om hans behov for at blive anerkendt af de andre familiemedlemmer som subjekt for retfærdighed. Noget tilsvarende gør sig gældende i størstedelen af Kafkas andre historier om retfærdighed: de substantive fordelingskampe bliver gerne fremstillet i et komisk lys, men det skyldes ikke, at retfærdigheden som sådan er en farce; det skyldes snarere, at Kafka har forskudt sin opmærksomhed fra retfærdighedens hvad til retfærdighedens hvem. Kafkas litterære værker beskæftiger sig ikke med retfærdigheden på første, men på andet niveau. De spørger ikke "Hvad er retfærdigt?", men "Hvem er subjekt for retfærdighed?"

\section{Fejlindramning}

"Misframing" er Nancy Frasers navn for den særlige form for anden ordens uretfærdighed, der gør, at et menneske ikke tæller som juridisk person. Med en "ramme" mener Fraser de grundlæggende og selvfølgelige antagelser, der bestemmer, hvordan et menneske kommer på tale eller ikke kommer på tale som subjekt for retfærdighed. Når jeg insisterer på at sondre mellem at analysere de rettighedsløses katastrofe som henholdsvis et spørgsmål om ret og et spørgsmål om retfærdighed - selvom det unægtelig lyder som en strid om ord - så er det, fordi denne sondring tydeliggør afstanden mellem to forskellige opfattelser af denne grundlæggende fejlindramning. Hvis man nærmer sig problemet som et spørgsmål om ret, vil man forstå det underliggende rammeværk som det, der hedder en retsramme, og det vil sige som et repertoire af sociale regler, der har juridisk eller i hvert fald kvasijuridisk karakter. Hvis man i stedet nærmer sig problemet som et spørgsmål om retfærdighed, vil man snarere forstå rammeværket som det, man plejer at kalde en forståelsesramme, og det vil sige som noget langt bredere og langt blødere, der også omfatter de uskrevne regler og kulturelle forestillinger, der ligger til grund for vores forståelse af den sociale orden. Retfærdighed er ganske enkelt et mere omfattende problem end ret. 
Fraser selv siger ikke så meget om, hvordan man nærmere skal forstå den grundlæggende ramme, der kan fejlindramme et menneske. Hun taler om de fælles "ontologiske antagelser", der i langt de fleste diskussioner bliver forudsat som en selvfølgelighed (Fraser 2008b, 15ff), og om den "rammesættende grammatik" (grammar of frame-setting), der ligger til grund for de fleste diskussioner af første-ordens retfærdighed (s. 25). En mere udfoldet analyse af forholdet mellem kulturelle forståelsesrammer og retfærdighed er i de seneste år blevet tilbudt af en række teoretikere, der befinder sig i spændingsfeltet mellem politisk filosofi og kulturvidenskab, mest prægnant af Charles Taylor, Jacques Rancière og Judith Butler. Jeg vil foreslå begrebet social forestillingsverden som en betegnelse for vores fælles repertoire af forestillinger om vores fælles liv, en slags implicit kort over det samfundsmæssige liv. Man kan også vælge en mere moderne metafor og tale om en social GPS, der gør det muligt for mennesker at bevæge sig rundt mellem hinanden i samfundet. Taylor skriver om "social imagination", Rancière om "partage du sensible" og Butler om "frames", og selvom de tre teoretikere langtfra har sammenfaldende ærinder, er de dog enige om at beskrive denne ureflekterede og før-teoretiske baggrundsforståelse som afgørende for, hvordan det sociale liv kommer til syne. Eller mere specifikt: som afgørende for hvem der overhovedet kan blive synlig på samfundets moralske radar som subjekt for retfærdighed. Formuleret med Taylor er den sociale forestillingsverden det uomgængelige rammeværk, der ligger bag alle forestillinger om distributiv retfærdighed i form af en fælles forståelse af, hvem der er medlemmer af samfundet, og hvem der ikke kan tilskrives en anden status end en sten (Taylor 1985, 296ff; 1989).

I "Forvandlingen" er uretfærdigheden lokaliseret på den sociale forestillingsverdens niveau og ikke på de sociale reglers niveau. Fortællingen drejer sig kun i beskeden grad om, hvilke specifikke krav Gregor kan gøre gældende; det afgørende er, hvordan han selv og hans nærmeste fortolker hans stilling i familiens sociale orden. Det er vel at mærke sjældent, at den slags fortolkninger bliver begrebsligt formuleret i det fiktive univers. Langt oftere tager de form som en slags mavefornemmelse for orden, og det vil sige som en umiddelbar og affektiv reaktion på Gregors tilstedeværelse: en voldsom medfølelse med hans sygdom, en uovervindelig væmmelse ved hans stank eller hans udseende, en lystblandet vrede over hans fors $\varnothing g$ på at forlade sin foreskrevne plads i familiens orden, og til allersidst blot en mat ligegyldighed over at stadset er blevet skaffet af vejen.

"Misframing" er med andre ord ikke kun et normativt, men også et ontologisk problem: det drejer sig ikke kun om, hvad jeg må, men også mere grundlæggende om, hvem jeg er i egne og andres øjne. Denne "socio-ontologiske" eller "ontopolitiske" (Connolly 1995) dimension får Arendt ikke med. Når hun analyserer de rettighedsløses katastrofe som et spørgsmål om subjektive rettigheder, undlader hun at stille spørgsmålet om det subjekt, hvis ret der er tale om. I Arendts perspektiv er subjektet ganske enkelt og helt uproblematisk til stede, lidt ligesom en velvoksen flygtning der stiger af toget i en fremmed by med sin kuffert i hånden. Spørgsmålet er blot, om dette subjekt har en ret til at have rettigheder, på samme måde som det kan være et spørgsmål om subjektet har en kuffert i hånden eller ej (Menke 2007). I Kafkas analyse af de rettighedsløses katastrofe er subjektet ikke en uproblematisk 
realitet, der har eller ikke har rettigheder, men snarere et problematisk produkt af de kulturelle forståelsesrammer, hvorigennem det sociale liv kommer til syne. Der er ikke tale om en retslig katastrofe, men om en mere dybtliggende kulturel katastrofe i den sociale forestillingsverden.

\section{Stereotyper}

I essayet "The Jew as Pariah" viser Arendt, hvordan de jødiske forfattere var i stand til at "udvikle begrebet om pariaen som en mennesketype" (Arendt 1978, 68). Heines litterære værker tilbyder eksempelvis et "portræt" af ham selv som en paria, der er udstødt fra det organiserede samfund, og på tilsvarende vis er Kafka blot det seneste eksempel på "typificeringen" af pariaen (ibid., 71, 82). "Det typiske" blev dannet som sociologisk begreb af Max Weber (Weber 1949, 88) og udviklet til et litteraturvidenskabeligt analyseredskab af Georg Lukács (Lukács 1962, 478 vol. 6). Ifølge Lukács' realismeteori er det mylder af bankmænd, journalister, grevinder og unge digtere, der befolker Balzacs fiktive Paris, "typiske" for så vidt som de inkarnerer en række væsentlige træk i den bestemte historiske situation, som så i anden omgang er elegant forbundet med det individuelle menneskes brogede særegenheder. Ved at læse Kafkas litterære værker som en repræsentation af pariaens sociologiske type lægger Arendt sig i forlængelse af en dominerende tradition i den tidlige Kafkaforskning. Uanset om den teoretiske ramme var marxistisk, freudiansk, heideggersk eller bare helt almindeligt biografisk, opfattede de fleste tidlige læsere Kafkas litterære værker som avancerede typologier. Den bærende hermeneutiske ambition var at forstå værkernes gådefulde hovedpersoner - Georg, Karl, Gregor, Josef K, K., osv. - som lige så mange stedfortrædere for Kafkas egen psykologiske eller sociologiske type. Begrebet om det 'kafkaske', der tog form i disse år, er i sig selv et typologisk begreb, der (for at genbruge Villy Sørensens formulering) betegner en bestemt form for "psykiske komplekser", sådan som de træder frem i en bestemt form for social omverden.

Kafka noterer et sted, at han har "den yderste modvilje mod ordet 'type"' (Kafka 1990, 982). Det er også indlysende, at dette ord ikke er til nogen hjælp i en fortolkning af "Forvandlingen". Menneskestore biller kan ikke hævdes at have været typiske i Prags borgerskab i starten af forrige århundrede. Hvis ordet type har nogen relevans i denne forbindelse, er det med andre ord ikke på den sociale virkeligheds niveau, men snarere på den sociale forestillingsverdens niveau. Typerne ville da være det, som det man i dag plejer at kalde stereotyper: faste kulturelle forestillingsformer hvormed vi formaterer vores fortolkning af hinanden.

Hannah Arendts første mand, Günter Anders, kan levere et eksempel på, hvordan Kafka håndterer den slags stereotyper. I sin skoledannende læsning af "Forvandlingen" fra 1951 pegede Anders som den første på, at ordet "kryb" (Ungeziefer) jo er et skældsord. Kunstnere er i andre menneskers øjne "beskidte biller", skriver Anders, og det er derfor, Gregor vågner op en morgen og virkelig er en bille. Et mere nærliggende eksempel leveres måske af Hermann Kafka, der et par måneder før Kafka gik i gang med "Forvandlingen" brugte det samme skældsord om Kafkas gode ven Jitzchak Löwy: "Den der sover med hunde, står op med utøj” (Kafka 1990, 223). 4 "Forvandlingen" forvandler med andre ord en retorisk figur til et empirisk 
faktum; skældsordet får ben at gå på i det fiktive univers. ${ }^{5}$ Som Anders selv opsummerende skriver om Kafka: "Han trækker på sprogets foreliggende lager, dets billedkarakter. De metaforiske ord tager han på ordet" (Anders 1951, 40).

Arendt undgår spørgsmålet om litterær form i sin læsning af Kafka, og for den sags skyld også i sine læsninger af Varnhagen, Heine, Dostojevskij og Melville. Det virker som om, hun grundlæggende opfatter den litterære form som et transparent medium, gennem hvilket man kan skaffe sig adgang til de interessante sociologiske typer, i dette tilfælde den jødiske parias type. I Kafkas analyse af de rettighedsløses katastrofe er den litterære form derimod afgørende. Denne analytiske tilgang retter nemlig sit fokus ikke mod de sociale typer, som værket giver et billede af, men mod de kognitive stereotyper, som fortællerne og de fiktive figurer selv bruger til at danne sig et billede af det sociale rum, som de færdes i. Med Anders' formulering synliggør Kafkas bogstaveliggjorte metafor "sprogets foreliggende lager, dets billedkarakter". At få metaforer til at mutere på den måde er et litterært greb, der fremmedgør - dvs. distancerer og demonstrerer - den sociale forestillingsverden og dens indbyggede fejlindramninger. Kafkas værker er ikke dokumenter om de rettighedsløse katastrofe, men instrumenter til at tænke over denne katastrofe.

\section{Det nøgne liv}

I de seneste år har Giorgio Agambens filosofi spillet en afgørende rolle for, hvordan man i Kafka-forskningen har forstået forbindelsen mellem Arendt, Kafka og undtagelsestilstanden (hvilket som nævnt er Agambens begreb for de rettighedsløse katastrofe). Ifølge Agamben giver Kafkas værker et billede af suverænens ekstra-retslige magtudøvelse, sådan som den finder sted i undtagelsestilstanden. Det gælder ikke mindst den berømte parabel "Foran loven", hvor dørvogteren ved porten til loven ikke giver manden fra landet tilladelse til at træde inden for i loven, men lader ham vente hele resten af hans liv ude foran porten (Agamben 1998, 49). På to afgørende punkter ligger Agambens Kafkakommentarer i umiddelbar forlængelse af Arendts, og det vil sige i forlængelse af det, som jeg har redegjort for i denne artikel. For det første understreger Agamben, at de rettighedsløses problem, med Arendts formulering, må forstås som noget "meget mere fundamentalt end retfærdighed". Hos Kafka drejer det sig ikke så meget om de rettigheder, som man kan nyde godt af, når man er kommet sikkert gennem porten til loven; det drejer sig snarere om forholdet mellem loven og det nøgne liv uden for loven. I Agambens Carl Schmitt'ske optik rejser menneskets placering "foran loven" et spørgsmål om det grundlæggende forhold mellem lovens og livets sfære: om hvordan Kafkas fiktive figurer overhovedet er blevet "impliceret" eller "indskrevet" i lovens sfære (Agamben 2011, 24). For det andet understreger Agamben, helt i tråd med Arendt, at det menneske, der står og venter i undtagelsestilstandens retslige vakuum "foran loven", bliver dehumaniseret og bestialiseret, $\mathrm{fx}$ ved at blive forvandlet til en varulv. Når undtagelsestilstanden får byen til at gå op i fugerne, indtræder menneskene i en zone, hvor de ikke længere er til at skelne fra dyr (Agamben 1998, 107).

Der er imidlertid en forskel mellem Arendts og Agambens beskrivelse af de rettighedsløses katastrofe, der har afgørende konsekvenser for forståelsen af Kafkas 
forfatterskab. For Arendt er rettighedsløsheden en katastrofe, fordi ret er det eneste, vi har, der kan beskytte mennesket mod andre menneskers vilkårlige magtudøvelse. Dette var hendes egen bitre erfaring fra sine mange år som flygtning fra Nazityskland. For Agamben, derimod, er rettighedsløsheden ikke så meget en katastrofe som en messiansk mulighed. Her handler det ikke om at restaurere et organiseret politisk rum omkring den rettighedsløse flygtning eller lejrfange, men om helt at fritskrabe mennesket fra retten. Ifølge Agambens lidt forcerede læsning er manden fra landet, der bruger sit liv på at sidde og vente foran porten til loven, i virkeligheden en model for en frigørelsesstrategi - og dermed en fætter til skriveren Bartleby (Agamben 1999, 243-271). Ligesom K., hovedpersonen i Kafkas Slottet, ifølge Agamben ikke kæmper for at blive medlem af landsbyens normative fællesskab; han kæmper ganske enkelt mod loven (Agamben 2011, 23). Agamben peger på denne forskel mellem sig selv og Arendt, når han i slutningen af Homo sacer kritiserer Arendt for at ville "restaurere" den traditionelle politiske filosofis begreber (s. 187). Hvor Arendts projekt, som vi har set, var at konstruere en ny, grundlæggende menneskeret, der kan sikre alle mennesker en plads i det politiske rum, der er Agambens projekt snarere at dekonstruere ethvert begreb om menneskeret (Agamben 2000, 19).

Det andet vigtige problem i Agambens Kafka-kommentarer deler han med Arendt, for det består i, at de begge diskuterer de rettighedsløses katastrofe som et spørgsmål om ret og ikke som et spørgsmål om retfærdighed. Agamben forstår det nøgne liv i det normative vakuum ud fra de juridiske eller quasi-juridiske regler, der bliver etableret og suspenderet i den suveræne beslutning, og set i den optik bliver rettighedsløsheden iscenesat som et retligt problem: som en tæt og dødelig dans mellem loven og livet. ${ }^{6}$ Hverken Arendt eller Agamben interesserer sig for den mere diffuse form for uretfærdighed, der handler om, hvordan mennesket kommer til syne i den sociale forestillingsverden. Når Agamben læser Kafkas "Foran loven", er han eksempelvis blind for de halvvejs forstyrrede forestillinger, som manden fra landet gør sig om dørvogteren og loven - selvom det faktisk er mandens sociale forestillingsverden, som Kafkas tekst bruger mest plads på at analysere. I modsætning til Arendt og Agamben har jeg i denne artikel insisteret på at forstå de rettighedsløses katastrofe som et spørgsmål om retfærdighed, og vel at mærke som en form for meta-retfærdighed, der ikke befinder sig på de sociale reglers niveau, men på den sociale forestillingsverdens mere grundlæggende niveau.

Hvis man sammenfatter mine to kritikpunkter af Agamben (hvoraf det ene kritikpunkt altså er hentet hos Arendt, mens det andet retter sig mod både hende og Agamben), kan man diagnosticere Agambens Kafkalæsning som moderne 'kafkask'. I modsætning til Villy Sørensens og 50'erne og 60'ernes øvrige klassiske 'kafkaske' Kafkafortolkninger reducerer Agamben ikke det sociale liv til en projektionsvæg for det psykiske liv. Men han fastholder ikke desto mindre den velkendte 'kafkaske' opstilling, hvor det stakkels forsvarsløse menneskeliv bliver knust af absurde bureaukratiske institutioner. Denne 'kafkaske' modstilling mellem livets og lovens sfære gør det umuligt at få øje på, at der faktisk foregår en diskussion af uretfærdighed i Kafkas fiktive værker. Hos Kafka er idealet om retfærdighed ikke bare en fjern messiansk utopi, men derimod et langt mere konkret spørgsmål om, hvem der er med- 
lem af det normative fællesskab, og hvem der ikke er: om Gregor tæller eller ikke tæller med som en del af Samsa-familien.

Hvis jeg afslutningsvis gav mig selv den suveræne magt til at beslutte, hvad ordet 'kafkask' skulle betyde fremover - så at ordet faktisk kunne gøre nytte og ikke bare skade i fortolkningen af Kafkas litterære værker - så ville jeg dekretere, at man fra nu af skulle bruge ordet som en betegnelse for en form for uretfærdighed, der skyldes den fælles forestilling om det fælles liv: en slags kognitiv forvrængning, der ligger så dybt i kulturen, at den ikke kan ekspliciteres og diskuteres i juridiske og politiske begreber, men kun kan synliggøres i Kafkas avancerede litterære form. Udlændingeservices bureaukratiske procedurer ville ikke være 'kafkaske' i denne betydning af ordet, men det ville til gengæld den danske befolknings repertoire af forestillinger om rigets truede grænser.

\section{Noter}

I Villy Sørensen er her inspireret af Walter Sokels “drømmeprincip”, som Sokel forklarer i en programagtig formulering: "Alle Aussagen der Kafkaschen Erzählkunst sind verhüllender Ausdruch eines alle beherschenden Innerlichen" (Sokel 1983, 9).

2 Se hertil fx (Birmingham 2006).

3 Se hertil (Appadurai 1996; Butler 2009; Rancière 2000; Taylor 2004).

4 Kafka gentager og udfolder episoden i sit brev til faderen, og denne gang kaldes Löwy ligefrem et "Ungeziefer", altså samme ord som Gregor i "Forvandlingen" (Kafka 1992, 154).

5 I forlængelse af Günther Anders har først og fremmest Theodor W. Adorno og Stanley Corngold interesseret sig for Kafkas legemliggørelse af metaforen, og begge tager ligesom Anders udgangspunkt i Gregor Samsas billekrop. Under stærk inspiration fra Kafka (og fra Benjamins Kafka-studier) opstiller Adorno i Kierkegaard. Konstruktion af det æstetiske fra 1933 en teori om Kierkegaards "bogstavelige metaforer" (Adorno 1996, 33). I 1955 tilbagefører han dette begreb fra Kierkegaard til Kafka: “'De rejsende er som biller', hedder den talemåde som Kafka må have grebet fat i, og spiddet som et insekt. Biller, ikke som biller" (Adorno 1973, 266). I artiklen "The Metamorphosis: Metamorphosis of the Metaphor" (revideret udgave 1988) lægger Stanley Corngold sig i forlængelse af Adorno, men tilbyder en mere teoretisk reflekteret beskrivelse af den bogstaveliggjorte metafor (Corngold 1988).

6 Agambens (og Carl Schmitts) snævre fokus på forholdet mellem suverænen og loven har i de seneste år været udsat for heftig (og efter mine begreber berettiget) kritik af en række politiske filosoffer, se fx (Honig 2009; Lazar 2009; Menke 2004).

\section{Litteratur}

Adorno, T. (1973). Prismen: Ohne Leitbild. Frankfurt am Main: Suhrkamp.

Adorno, T. (1996). Konstruktion af det æstetiske (J. Dehs, Trans.). København: Gyldendal.

Agamben, G. (1998). Homo sacer: Sovereign Power and Bare Life. Stanford, Calif.: Stanford University Press.

Agamben, G. (1999). Potentialities: Collected Essays in Philosophy. Stanford: Stanford University Press. Agamben, G. (2000). Means without End: Notes on Politics. Minneapolis: University of Minnesota Press. Agamben, G. (2011). Nudities. Stanford: Stanford University Press. 
Anders, G. (1951). Kafka pro und contra. Die Prozess-Unterlagen. München: C.H. Beck.

Appadurai, A. (1996). Modernity at Large: Cultural Dimensions of Globalization: University of Minnesota Press.

Arendt, H. (1949). "The Rights of Man": What Are They? Modern Review, 3:1.

Arendt, H. (1974). Rahel Varnhagen: the Life of a Jewish Woman. New York: Harcourt Brace Jovanovich.

Arendt, H. (1978). The Jew as Pariah: Jewish Identity and Politics in the Modern Age. New York: Grove Press.

Arendt, H. (1979). The Origins of Totalitarianism (New ed.). San Diego, Calif.: Harcourt Brace Jovanovich.

Arendt, H. (2005). Menneskets vilkår (C. Dahl, Trans.). København: Gyldendal.

Arendt, H. (2007). The Jewish Writings. New York: Schocken Books.

Arendt, H. (2010). Franz Kafka: en revurdering. I anledning af 20-årsdagen for hans død. In M. Thorup (Ed.), Eksistens og religion. Tænkning mellem tradition og modernitet. Århus: Klim.

Aristoteles (1997). Statslære (W. N. o. P. Fuglsang, Trans. 2. udgave ed.). København: Gyldendal.

Aristoteles (2000). Etikken (S. Porsborg, Trans.). Frederiksberg: Det lille Forlag.

Birmingham, P. (2006). Hannah Arendt \& Human Rights: the Predicament of Common Responsibility. Bloomington, Ind.: Indiana University Press.

Burke, E. (1987). Reflections on the Revolution in France. Cambridge: Hackett

Butler, J. (2009). Frames of War: When is life Grievable? London: Verso.

Connolly, W. E. (1995). The Ethos of Pluralization. Minneapolis; London: University of Minnesota Press.

Corngold, S. (1988). Franz Kafka: the Necessity of Form. Ithaca: Cornell University Press.

Fraser, N. (2008a). Abnormal Justice. Critical Inquiry, 34(3), 393-422.

Fraser, N. (2008b). Scales of Justice: Reimagining Political Space in a Globalizing World. Cambridge: Polity.

Honig, B. (2009). Emergency Politics: Paradox, Law, Democracy. Princeton: Princeton University Press. Kafka, F. (1990). Tagebücher. Frankfurt am Main: S. Fischer.

Kafka, F. (1992). Nachgelassene Schriften und Fragmente II. Frankfurt am Main: S. Fischer.

Kafka, F. (2008). Fortællinger (V. S. Isak Winkel Holm, Per Øhrgaard, Trans.). København: Gyldendal. Lazar, N. C. (2009). States of Emergency in Liberal Democracies. Cambridge: Cambridge University Press. Lukács, G. (1962). Werke. Neuwied am Rhein: Luchterhand.

Menke, C. (2004). Spiegelungen der Gleichheit: politische Philosophie nach Adorno und Derrida (Erw. Taschenbuchausg., 1. Aufl. ed.). Frankfurt am Main: Suhrkamp.

Menke, C. (2007). The "Aporias of Human Rights" and the "One Human Right": Regarding the Coherence of Hannah Arendt's argument. Social Research, 74, 739-762.

Rancière, J. (2000). Le partage du sensible: esthétique et politique. Paris: Fabrique.

Sokel, W. H. (1983). Franz Kafka - Tragik und Ironie. Zur Struktur seiner Kunst. Frankfurt am Main: Fischer.

Sørensen, V. (1980). Kafkas digtning (2. udgave, 1. uglebogsoplag ed.). København: Gyldendal. Taylor, C. (1985). Philosophy and the Human Sciences. Cambridge: Cambridge University Press. Taylor, C. (1989). Sources of the Self: the Making of the Modern Identity. Cambridge, Mass.: Harvard University Press.

Taylor, C. (2004). Modern Social Imaginaries. Durham, N.C.: Duke University Press.

Walzer, M. (1983). Spheres of Justice: a Defense of Pluralism and Equality. New York: Basic Books.

Weber, M. (1949). Max Weber on the Methodology of the Social Sciences. New York: Free Press. 